\title{
DEVELOPING ONLINE SENSE OF COMMUNITY: GRADUATE STUDENTS' EXPERIENCES AND PERCEPTIONS
}

\author{
Dr. Jesus TRESPALACIOS \\ ORCID: 0000-0002-3162-3601 \\ Department of Educational Technology \\ Boise State University \\ Boise, USA \\ Dr. Lida J. URIBE-FLOREZ \\ ORCID: 0000-0001-8254-4228 \\ Department of Educational Technology \\ Boise State University \\ Boise, USA
}

Received: 16/01/2019 Accepted: 25/02/2019

\begin{abstract}
Building a sense of community ( $\mathrm{SoC}$ ) is an important process in the success of distance education and students' retention. However, developing a community in online learning environments is not an easy task. The purpose of this research study is to explore perceptions of graduate students on SoC and learning after using different collaborative activities with diverse forms of interaction (text, audio, and video) in an online educational research course. Quantitative data from two surveys and qualitative data from individual interviews were collected. Findings indicate that multimodal and scaffolding interactive activities help to support connectedness and learning, and therefore foster online graduate students' sense of community. The results of this study add to the literature with regard to instructional strategies used to support the development of online sense of community.
\end{abstract}

Keywords: Sense of community, online learning, distance education, instructional design.

\section{INTRODUCTION}

Community is a prominent concept in educational contexts. For instance, previous research regularly discussed about communities of learners (Jonassen, 1995; Rogoff, 1994), communities of practice (Barab \& Duffy, 2012; Wenger, 1998, 2000), knowledge-building communities (Scardamalia \& Bereiter, 1994), learning communities (Hill, 2012; Lenning \& Ebbers, 1999; Retallick, Cocklin \& Coombe, 1999), community of inquiry (Garrison, 2017), and professional learning communities (DuFour \& Eaker, 1998; Stoll et al., 2006). While the concept of community differs in ways in each of these lines of research, a common characteristic is the bounded group of students involved in cooperative learning through meaningful interaction with others (Misanchuk \& Anderson, 2001). Community takes on even more relevance for online educators because their students typically do not have a chance to meet and learn in the same place and time, which could lead to feelings of isolation and loneliness (Ludwig-Hardman \& Dunlap, 2003; McInnerney \& Roberts, 2004).

Early educators began experimenting with ways to create communities in their learning environments. Cross (1998) summarized this interest in three broad categories: (1) a change in the philosophy of knowledge based on a social construction, (2) research on learning outcomes, motivation, cognition, and intellectual development, and (3) pragmatic reasons such as educating students for the workforce and responsible citizenship. Especially for online education, interest on developing online communities led to a number of popular books (see Haythornthwaite \& Kazmer, 2004; Luppicini, 2007; Palloff \& Pratt, 1999, 2004, 2007; Tu, 2004). Besides the general recognition of its relevance, there is a need to conduct studies from diverse programs, populations, and disciplines to understand the perceptions of online participants toward community building (Liu, Magjuka, Bonk \& Lee, 2007; Luo, Zhang \& Qi, 2017). Based on previous 
research on instructional activities that support the building community in online environments, this study was designed to explore students' online learning experiences with multiple interactive activities. Thus, working with a specific population of online students enrolled in a cohort-based Doctor of Education (EdD) program, the purpose of this study was to investigate graduate students' perceptions of both the course and sense of community. The research questions that guided this study stated: In an online graduate course on educational research,

- How do students rate the course and its sense of community?

- What are students' perceptions about the relevance of interactive activities to promote learning and community?

\section{LITERATURE REVIEW}

Among the many factors that impact student success in online courses, the development of online communities has become an important area of interest, especially in higher education

(Bond \& Lockee, 2014; Roberts \& Lund, 2007). However, developing an online learning community is not an easy task (Hill, 2012). In the following paragraphs, previous studies on instructional strategies to develop sense of community are presented along with a discussion on synchronous and asynchronous activities to promote collaboration. Finally, the community of inquiry model (CoI) (Garrison, Anderson, \& Archer, 2000) is reviewed as a framework to analyze students' perception about the relevance of collaborative activities to promote learning and community.

\section{Building Sense of Community}

Rovai (2002b) supported that virtual classrooms have the potential to develop sense of community at the levels of traditional classrooms and defined classroom community based on four dimensions: spirit (recognition of membership), trust (willingness to rely on other members of the community), interaction (either task-driven or socio-emotional in origin), and commonality of expectation and goals (learning). Brown (2001) also identified a three-stage process for building community in distance learning classes: making friends for a comfortable communication, community conferment (acceptance), and camaraderie that is achieved after a long-term relationship.

There have been several attempts to identify general recommendations to promote community in online environments (see Table 1). One constant recommendation, included in more recent studies (Luo, Zhang, \& Qi, 2017; Oha, Ozkaya, \& LaRose, 2014), is the design of collaborative activities that promote interactions. For instance, Shackelford and Maxwell (2012a) found the learner-learner interactions that are most predictive to a sense of online communities are introductions, collaborative group projects, sharing personal experiences, whole-class discussions, and exchanging resources. Using Rovai's (2002a) Classroom Community Scale (CCS), Dawson (2006) also found that students who communicate more with peers and staff have a significantly higher degree of sense of community. Thus, research supports that sense of community $(\mathrm{SoC})$ can be developed in an online learning environment through interactions. However, these interactions do not spontaneously take place and it is relevant that students share a sense of online community (Gunawardena, 1995). As Wegerif (1998) stated, "Forming a sense of community, where people feel they will be treated sympathetically by their fellows, seems to be a necessary first step for collaborative learning." (p. 48). Thus, there is a necessity to mediate group activities that promote interaction and collaborative learning. 
Table 1. Some recommendation/activities to promote online sense of community

\begin{tabular}{|c|c|}
\hline Authors & Recommendation/Activities \\
\hline Berry (2017) & $\begin{array}{l}\text { Create a warm and welcoming tone, use technology to provide } \\
\text { supportive feedback and to engage all students, and create a } \\
\text { personalized learning experience. }\end{array}$ \\
\hline $\begin{array}{l}\text { Haythornthwaite, Kazmer, Robins, and Shoemaker } \\
\text { (2000) }\end{array}$ & $\begin{array}{l}\text { Promoting initial bonding, monitoring and supporting continued } \\
\text { interaction and participation, and providing multiple means of } \\
\text { communication to support the need to engage in work and social } \\
\text { interaction, both publicly and privately. }\end{array}$ \\
\hline Palloff and Pratt (2007) & $\begin{array}{l}\text { Interaction/communication, social presence, negotiated guidelines, } \\
\text { effective course design, and collaborative/transformative learning. }\end{array}$ \\
\hline Rovai (2002b) & $\begin{array}{l}\text { Transactional distance, social presence, social equality, small group } \\
\text { activities, group facilitation, teaching style and learning stage, and } \\
\text { community size. }\end{array}$ \\
\hline Shackelford and Maxwell (2012b) & $\begin{array}{l}\text { Instructor modeling, support and encouragement, facilitating } \\
\text { discussions, multiple communication modes, and required } \\
\text { participation. }\end{array}$ \\
\hline Swan et al. (2000) & $\begin{array}{l}\text { Consistency in course design, contact with course instructors, and } \\
\text { active discussion. }\end{array}$ \\
\hline
\end{tabular}

\section{Synchronous and Asynchronous Collaborative Activities}

It has been empirically shown that the success of online learning courses depends on designing collaborative learning activities (Hrastinski, 2008a). Multiple studies agreed that discussions activities in online learning environments promote students' learning through collaboration (An, Shin, \& Lim, 2009; Hew \& Cheung, 2013; Kent, Laslo, \& Rafaeli, 2016). Furthermore, online discussions also facilitate social interaction among students providing opportunities to share not only task-related messages but also thoughts about daily life (Cho \& Tobias, 2016). Embedded in the process of discussing in online environments, it is the construct of interactivity (Ken, Laslo, \& Rafaeli, 2016). Based on the social-constructivist pedagogy of distance education and the development of two-way communication technologies, synchronous and asynchronous interactions are relevant activities to create opportunities for students' construction of knowledge (Anderson \& Dron, 2011).

In one hand, asynchronous discussions forums can be defined as "technological resources that enable members of a group to interact in different times and locales to explore topics and discuss ideas from different perspectives through messages that remain as longs and can be complemented" (Luhrs \& McAnally-Salas, 2016, p. 31). Asynchronous activities are a widely used strategy in distance education to bring students and the instructor together to facilitate critical discourse and reflection based on an initial query posted at the begging of the session (Trespalacios \& Rand, 2015). However, as could happen with lectures or problem-based environments, asynchronous online discussions bring also limitations like students' feelings of disconnection (Andresen, 2009). Although asynchronous text-based discussions are one the most commonly used communication strategy (De Wever, Schellens, Valcke, \& Keer, 2006), online discussions can have different formats and designs such as students-led versus instructor-led, text-based versus audio or video-based, small-groups vs whole-class, and synchronous versus asynchronous discussions. These different formats allow multiple combinations like instructor-led video-based synchronous discussions developed using Google Meet or Zoom technologies. For example, Ice, Curtis, Phillips, and Well (2007) found that the use of asynchronous audio feedback was associated with feelings of increased involvement, enhanced learning community interactions, and retention of content, and with the perception that the instructor cared more about the student.

On the other hand, synchronous e-learning, supported by video conference or chat rooms, has the potential to help online students in the development of communities (Hrastinski, 2008b) and learning through interactions (Martin, Parker, \& Deale, 2012). For instance, in live synchronous web meetings, students and instructor organize their schedules to meet at the same time but not in the same place enhancing learners' sense of community (Fadde \& Vu, 2014). Thus, in asynchronous online courses, synchronous activities provide additional elements to the interactions such as instant communication and feedback that help establish other as being "real" and "there" (Lowenthal, Dunlap, \& Snelson, 2017). 


\section{Community of Inquiry}

To analyze students' perception about the relevance of collaborative activities to promote learning and community, this study draws upon the community of inquiry model (CoI) (Garrison, Anderson, \& Archer, 2000). Grounded in a collaborative constructivist view of teaching and learning, the CoI is defined "as a group of individuals who collaboratively engage in purposeful critical discourse and reflection to construct personal meaning and confirm mutual understanding." (Garrison, 2011, p. 15). According to the CoI framework, there are three interdependent presences to support the development of meaningful learning experiences in a community of learners: social, cognitive, and teaching presence. Social presence is defined as "the ability of participants to identify with a group, communicate openly in a trusting environment, and develop personal and affective relationships" (Garrison, 2017). Cognitive presence is defined "as the extent to which learners are able to construct and confirm meaning through sustained reflection and discourse." (Garrison, Anderson, \& Archer, 2001, p.11). Finally, teaching presence is defined as "the design, facilitation, and direction of cognitive and social presences for the purpose of realizing personally meaningful and educationally worthwhile learning outcomes" (Anderson, Rourke, Garrison, \& Archer, 2001, p. 90).

Previous research has already identified relationships between SoC and the different presences in the CoI (Shea, 2006). For instance, open and effective communication, defined as key aspects of the social presence, are also necessary to establish a sense of community in online learning environments (Garrison, 2007). Using Rovai's Classroom Community Scale, Shea, Li, and Pickett (2006) found a significant link between students' sense of community and effective instructional design and "directed facilitation" on the part of course instructors. Additionally, in a review of multiples studies, Garrison (2007) stated, "The consensus is that teaching presence is a significant determinate of student satisfaction, perceived learning, and sense of community." (p. 67). Finally, Rovai (2002c) found a significant relationship between classroom community and cognitive learning in an online educational environment.

\section{METHOD}

\section{Participants and Procedures}

Twelve students (five male and seven female) enrolled in an educational research online graduate course participated in this study. The demographic data shows that all the students in this course were mature, mostly over 30 years of age, and were full-time workers. All of them had a background in education with six participants currently working as teachers, two instructional coaches, two technology coordinators, one school librarian, and one working as a content specialist for a large publishing company. At the time of the study, eleven participants lived in the United States (i.e. three from the east coast and other three form the west coast) and only one participant lived overseas. Additionally, ten participants were Caucasian and two were Hispanic.

The three-credit course is required for all students in the Educational Technology doctoral program. Doctoral students enrolled in the cohort-based online EdD program are scheduled to take a foundational course on educational research during their second semester of the program. This course teaches students to review quantitative, qualitative, and mixed-methods research approaches in education, and focus on research studies and methodologies in Educational Technology. Additionally, students discuss preliminary elements that are necessary before designing a research proposal such as reviewing the literature, deciding on to use a theoretical framework, selecting an appropriate research methodology, and employing good writing and ethical practices.

\section{Setting}

The online graduate course in Educational Research had six instructional activities where students need to interact in different levels with their classmates, the instructor, and the content. These activities are (1) an introductory activity in VoiceThread where students post a video introducing themselves, watch other students' introductions, and record at least three posts to interact with their classmates; (2) a small-group presentations where students prepare a synthesis of a specific content of the course for the whole class; (3) 
three whole-group asynchronous discussions where students use the knowledge they have learned to answer two questions (Appendix A) and get involved in a discussion with their classmates; (4) synchronous video conversations with the instructor to ask questions or clarify doubts related to the course content; (5) a peerreview activity where students provide feedback to one of their classmate's final projects that consist of a proposal for a research study; and (6) a critique paper where pairs of students selected one peer-reviewed journal article and assessed it based on a specific set of guidelines. The main source of information in the course was Creswell's (2014) Educational Research: Planning, Conducting, and Evaluating Quantitative and Qualitative Research. The main goal of the course stated that at the end of the course students were able to develop a research proposal in educational technology. Thus, different activities like discussion questions and the content of the presentations were designed to help students to reach this main goal.

\section{Data Collection and Analysis}

Data for this study are from three sources: 1) Classroom Community survey, 2) course evaluation survey, and 3) synchronous semi-structured interviews. Quantitative data for the study was gathered from Rovai's (2002a) Classroom Community Scale (CCS) that examines sense of community in a learning environment. This survey has 20 Likert-scale questions (strongly agree, agree, neutral, disagree, and strongly disagree) composed of two subscales of connectedness and learning:

Connectedness represents the feelings of students regarding their cohesion, spirit, trust, and interdependence. Learning represents the feelings of students regarding the quality of their construction of understanding and the degree to which they share values and beliefs concerning the extent to which their learning goals and expectations are being satisfied. (Rovai, 2002c, p. 325).

CCS was administered at the end of the course as part of the course evaluation. This data was anonymous and the instructor had access to it after grades were submitted to the university system. Total possible classroom community scores range from 0 to 80 and scores on each subscale (learning and connectedness) can range from 0 to 40, with higher scores reflecting a stronger sense of community. Cronbach's coefficient alpha for the full classroom community scale was 0.93, suggesting strong reliability (Rovai, 2002a). Additionally, course evaluations filled anonymously by students at the end of the course were also used to obtain data regarding students' perceptions of this graduate course and the instructor. The survey contains twelve Likert scale questions with four questions related to the course design and eight questions related to the instructor performance (Appendix B). Finally, all twelve graduate students were invited to participate in a 20 to 30 minutes interview and seven participants accepted the invitation (Appendix C). Interviews were transcribed and texts were qualitatively analyzed reducing and interpreting the data to identify codes and themes (Saldana, 2015). In addition to the thorough description presented in the findings, peer debriefing was used to ensure the trustworthiness within this study. Peer debriefing was conducted with the second author during the qualitative analysis of the data, where codes and themes were questioned, justified, and verified until a total agreement was reached (Creswell \& Creswell, 2018). Additionally, to avoid possible discomfort to talk about the course with the instructor (first author), the second author, also a faculty in the same program, interviewed the students after they completed all the activities in the course.

\section{FINDINGS AND DISCUSSION}

To answer the first research question on how students rate the course and its sense of community, we analyzed data from the two surveys and we found that, on average, participants found positive the role of the instructor, the design of the course, and the development of sense of community on the online graduate course. As shown in Table 2, From the Classroom Community Scale survey, students agreed that the instructional activities designed in the course foster sense of community (62.3 out of possible score of 80). Results from the subscales showed that students agreed that they felt connected to each other $(29.1$ out of possible score of 40) and felt that they achieved their learning goals in the course (33.2 out of possible score of 40). Additionally, results from the course evaluation survey showed that students valued highly the performance of the instructor (seemed prepared, fostered learning, etc.), the assessment activities, instructional materials, and peer-collaboration activities as well (Appendix B). 
Table 2. Average scores from Rovai's survey

\begin{tabular}{lcc}
\hline & Mean & SD \\
\hline Total Learning community & 62.3 & 9.7 \\
Connectedness subscale & 29.1 & 6.2 \\
Learning subscale & 33.2 & 4.5 \\
\hline
\end{tabular}

To answer the second research questions related to the students' perceptions about the interactive activities to promote learning and community, seven of the twelve students accepted voluntarily the invitation to participate in a semi-structured interview. From these participants, five have been part of a cohort in our doctoral (EdD) program and two to the specialization in Ed Tech $(\mathrm{EdS})$ program. This could have impacted how participants perceived the SoC and collaboration in this course. However, one of the participants from the EdS program indicated "I think even if I hadn't known any of these people before this course, I would probably still have the same opinion of the activities." (Allison). Thus, the three major findings from the qualitative analysis are (1) Multimodal interactions support connectedness, (2) Scaffolding interactive activities support learning, and (3) Online collaboration is difficult but desired by graduate students. These findings are discussed below and supported by direct quotes from the students. Pseudonyms were used to protect the identities of the participants. Appendix $\mathrm{C}$ provides an example of the coding categories that were used for the study.

\section{Multimodal Interactions Support Connectedness}

When interpreting this finding using the CoI model, one recognizes that allowing students the opportunity to introduce themselves using videos, help them to project their individual personalities, and at the same, take the feeling of being part of a group promoting social presence (Garrison, 2011). Opposite to the written communication, video introductions allow students to show themselves and use spoken communication to present what they want about the job, hobbies, family, etc. Besides belonging to a cohort where they know each other from previous classes, participants had an opportunity to talk about themselves. As Allison indicated,

I thought that the voice thread introduction discussion was very helpful in getting what it was intended for, getting to know people and the fact that is... had the video component as well as the audio. . gave it a sense of really interacting with the people as opposed to just a text discussion which can help with the community. But, I think being able to put up the video, have other people respond with their videos and exchange communication that way, was very. . . it was really enjoyable, in terms of working with the other people on that.

Although VoiceThread introductory activity did not require multiple interactions, it helped participants to find affinity with members of the class. As Julia indicated,

...we made introductions, you shared some things about yourself, your vision, and what you wanted to research, and what you're hoping to gain. All of those things happened, but then it was kind of, I felt like, it up to me to go, 'Okay, these are the three people who are kind of interested in similar things. Now I'm going to keep an eye out for them in the forums.' I feel like it extended the opportunity for collaboration, but the activity in and of itself wasn't particularly collaborative.

The synchronous meetings with the instructor and members of the small group were described as a useful opportunity to support the teaching presence. For instance, Allison stated,

"it was helpful, again because it was alive, it was sort of a video chat. So, it was much more of a meeting type of feel more face to face, even though it's technologically mediated."

He went on and clarify,

"It was very helpful to get that opportunity to say okay, this is kind of the direction we're going in, does that make sense, is that the sort of thing you were looking for as an instructor." 
David also stated the preference for this activity,

"...we also had to meet with our professor and with the group of people that we were doing the VoiceThread with and ask him questions. I thought that was the most beneficial thing I did just because we had the face to face time with the professor and we were able to ask him questions regarding what we needed to do even globally about the whole class, not just about the project we were working on together."

This finding is related to Berry's (2017) conclusion on a study in online doctoral classrooms,

"instructors helped students develop a sense of community by creating a warm and welcoming tone in the classroom, and by using technology in a variety of ways to engage all students and create a personalized learning experience."

Thus, following the CoI model, the educator's role falls into the facilitation category trying to resolve students' issues (Garrison, 2011).

\section{Scaffolding Interactive Activities Support Learning}

A second common theme we noted in the data was the one related to the students' experiences with those activities that move them forward in the final course project. The majority of participants described the preferences for activities that emphasize the use concepts to prepare them for the development of a research proposal. For instance, discussing the whole-class asynchronous discussions, Frank stated,

"I really appreciated the content of the discussion boards because we had to apply what we were reading to our own research, our own research topics. By writing about research topics, and the research problems and questions, and different methods for qualitative and quantitative, I think posting that and getting feedback, not only from classmates but also the professor, I think was very helpful in really understanding how to create a research [proposal]..."

In the small group activity, participants needed to develop a VoiceThread presentation based on a few chapters of the course textbook identifying key issues, describing their relevance for the research process, and discussing how these key issues are relevant to them. For this activity, Sheri, who was a member of the first group, stated,

"It [presentation] required me to make sure that I really understood the reading. That is never a bad thing. We were all a little confused that the beginning of it about the fact that we had to apply it to ourselves. That made it even better because it wasn't just reiterate the reading, it was talk a little bit about how it applies to what you're thinking. It was- I thought it was useful."

In the CoI model, the cognitive presence is described in four phases: triggering (conceptualizing a problem), exploration (searching relevant information), integration (constructing meaningful solutions), and resolution (assessing the proposed solution). Combining the different learning activities such as asynchronous discussions, research proposal draft development, research proposal peer-review, and the completion of the research proposal helped to promote cognitive presence. For instance, having the creation of a research proposal as the main learning outcome of the course, the discussion questions were developed to trigger and explore potential topics that students would like to develop a research proposal. As recommended in the CoI model, participants had the freedom to select the topic based on their experience or previous studies (Garrison, 2017). During these discussions, participants responded to these questions and the classmates and the instructor provided feedback about the quality of their research ideas in the educational technology field. Additionally, to promote integration, the discussion questions were purposefully created in the way that students kept building the different sections of their research proposal based on the feedback obtained from the previous discussion. In this way, students have the time to reflect and integrate the feedback obtained during the discussions. Finally, to move into the resolution phase, students submitted an initial draft of the complete research proposal that was reviewed by one of their classmates. Participants reflect on the comments provided for the peer-review activity, asked questions if any, and submit the updated research proposal as the final course project. The peer-review was also another activity that was described relevant because participants had the opportunity to assess another classmate's research proposal. About this activity, Michael stated, 
"I already learned more from the reading of someone else's and critiquing someone else's almost than just my own. It provided the ability to support each other, those activities, and I liked that part. I think that did build community, that you're trying to help somebody else do a better job on their paper and identify things that you have questions about."

Michael went on an described the value of connected assignments to reach the course main goal,

"all the course activities support the process of writing the paper. Feedback from instructor and peers, discussions, etc. valuable for the final product."

\section{Online Collaboration is Difficult but Desired by Graduate Students}

Coinciding with previous studies on potential issues in online collaborative environments (Bennett, 2003; Reeves, Herrington, \& Oliver, 2004), participants described that collaboration in online education is difficult. Their busy lives with family and full-time jobs allow short periods of time to dedicate to their studies. This is an important issue when it is additionally required to meet and collaborate with classmates. Although students participated in a social event at the beginning of the semester and had a synchronous meeting to ask questions, participants had inconvenient to work together in small groups. For instance, in the critique paper activity, where participants chose their own partner agreed on a journal article where both are interested and write a critique, they liked it because was just two participants involved. For instance, Lisa indicated,

"For me the most relevant [activity] was the two person critique, the article critique. Mainly because just me and my partner, it was a kind of common interest and we were able to just kind of explore that into what it means personally for us in addition to from our own kind of research interests."

However, comparing this article critique paper with the small group presentation, where the instructor created the groups of four students, it was not the same experience. For instance, Julia compared them,

"That [critique paper] was very, very helpful. It was just nice to develop a relationship with one other person, through the remainder of the course... I think actually as opposed to, we did a presentation earlier in the semester, where there were four of us and that almost felt too big. There were a lot of moving parts, and it just kind of came down to, for us, establishing some roles. It ended up, I think, feeling less collaborative than the two person peer article review."

Michael also described difficulties preparing the VoiceThread presentation,

"I don't think we got together to actually discuss it." Michael went on, "Two of us in the group were working ahead, and two came during the last week to enter their things or maybe a day before it was due or two days before it was due."

Finally, David described explicitly the difficult to work collaboratively in online environments,

"As far as collaborating with other adults in an online environment, I think it's hard."

Asking participants recommendations to improve activities, there was a consensus that more interactive activities would be beneficial. Two specific recommendations came from the analysis of the data: (1) Relevance of instructor-led synchronous meetings: Looking for different types of communication besides text-based, having small groups meeting lead by the instructor have the potential to foster interactions and promote different presences from the CoI. For instance, David stated,

"I think the synchronous discussions force you into working with people or even discussing things with them in a different type of format than just the typing, because I would always pre-write all of my posts. I think it has some type of qualities to it that force people to be a little bit more genuine or make them think about things in a little bit of a different way."

Related to the more synchronous meeting, Lisa stated,

"The only suggestion I would have is to add a, I don't know what they call these... usually one anyway synchronous meeting just to ask questions or whatever, kind of talk to people. They're not mandatory."

(2) Improve the organization of small-group interactions: As was discussed in the previous finding, small group presentations were the less favorite activity because of the difficult to meet and organize the work. 
In the same way, the peer-feedback activity, where students assess the draft of one classmate and provide feedback and a separate Microsoft Word form, could be improved designing additional communication channels. For instance, talking about this peer-feedback activity, Julia recommended,

"I would almost love to see that kind offeedback in the context of a Google doc. Instead of submitting the Word document at that point, and then kind of pushing it out to someone else, if you were to be partnered with someone. For instance, I think I had [Maria]'s paper. Instead of me pushing out ... I guess just giving drafts that are more fluid, so that we could provide comments, but also, dialogue."

Lisa also made a recommendation in the whole-class asynchronous discussion to improve interactions,

"My only problem with the discussions is that they tended to be kind of too big as like everybody involved. It's overwhelming and it's hard to read everything."

Lisa went one and recommended,

"if say there are 20 people in class and you have four groups of five people you can get a little bit more detailed conversations going instead of maybe having to reply to if seven people, eight people reply to your initial post it just gets very difficult. But if it's only two, three people you're always talking to you can go a little bit more in depth I think."

Social interaction is an important aspect to foster collaboration. With a lack of social interaction, there is no real collaboration (Kreijns, Kirschner \& Jochems, 2003). Additionally, Kreijns et al. alerted us about two pitfalls while designing social interaction in computer-supported collaborative learning (CSCL): (1) Taking social interaction for granted, and (2) Restricting social interaction to cognitive processes. Authors went on and suggested four strategies to deal with these issues: (1) implement collaborative learning methods, (2) build interactivity, (3) change instructor's and/or learners' role, and (4) increase social presence. Thus, it is important to organize synchronous live events to make students more familiar with each other allowing more socio-emotional interactions to take place. It goes hand-in-hand with the social presence discussed in the CoI (Garrison, 2017). According to Gunawardena (1995), the development of social presence and a sense of community are the keys to promoting collaborative learning and knowledge building.

\section{CONCLUSIONS AND LIMITATIONS}

Although e-learning has allowed institutions to expand his education mission reaching more students outside of their physical boundaries, we are still at the beginning of understanding how to satisfy the educational needs of the more diverse population enrolled in our online education programs. As Desai, Hart, and Richards (2009) stated, "the challenge for learning institutions and instructors was to provide a sense of community with constructive feedback and provide open forthcoming communications as well as recognizing membership and feelings of friendship, cohesion, and satisfaction among learners." (p. 333). However, community in online courses rarely happens on its own. Instead, research suggests that instructors must plan for and facilitate the development of community online. We set forth to explore students' perceptions of classroom community and specifically how certain instructional strategies might help develop a sense of community in fully online graduate courses.

While our results should not be generalized to a larger population, they do serve as a starting point to investigate further how online educators can support the development of connectedness and at the same time promote student learning. This study helps to illustrate examples of different instructional activities and online interactions that can promote sense of community in an online learning environment. It describes some of the pros and cons that can arise when graduate students are learning collaboratively in an online environment. The study also reveals how the Community of Inquiry model can be a useful lens to analyze and design online environments that encourage sense of community between students.

Social and academic participation of students is essential to foster online communities (Misanchuk \& Anderson, 2001). When students were asked to describe the favorite aspects of the instructional activities, findings revealed that students preferred those activities that allow meaningful interactions with their classmates. Additionally, students recommend improving activities that allow better channels of communication that improve their interactions. On the other hand, asking students about their least 
favorite activities, they pointed mostly to the small group presentation because of the lack of communication that could allow them for a better organization and more productive interactions. These findings describe how online doctoral students are looking forward to working with their classmates, and instructors need to carefully consider designing such environments that support meaningful interactions through social, teaching, and cognitive presences. Looking together at the results from the surveys and the findings from the interviews, we can conclude that scaffolding interactive activities with multiple types of interactions help to support connectedness and learning, and therefore online graduate students' sense of community.

This study has potential limitations. First, it is the context in which study was conducted, including, the specific subject area (introduction to educational research), mode of course delivery (fully online course), the academic level of the course (doctoral level), and researchers' bias through the direct involvement with participants and data analysis. Finally, it should be noted that this study did not collect data about individual differences (e.g., prior knowledge, motivation, cognitive load, and self-regulated learning) or perceived value of the students about the course and teaching and the three dimensions of the community of inquiry model. To be able to triangulate the findings and draw inferences about the effects of the proposed learning tasks, future studies should collect these data types to describe more conclusive findings.

\section{BIODATA and CONTACT ADDRESSES of AUTHORS}

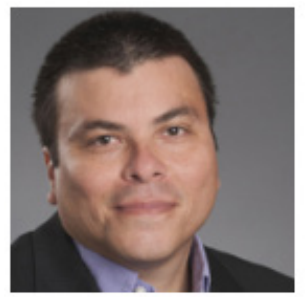

Jesus TRESPALACIOS, is an Associate Professor in the Department of Educational Technology at Boise State University. He teaches online graduate courses on instructional design and research methods. His scholarly activity includes online education, communities in online environments, and professional development for teachers. He earned his Ph.D. in Instructional Design and Technology from Virginia Tech.

Jesus TRESPALACIOS

Department of Educational Technology, Boise State University

Address: 1910 University Drive, Boise, USA

Phone: +01 2084267105

E-mail: jesustrespalacios@boisestate.edu

Lida J. URIBE-FLOREZ, is an associate professor at Boise State University and the

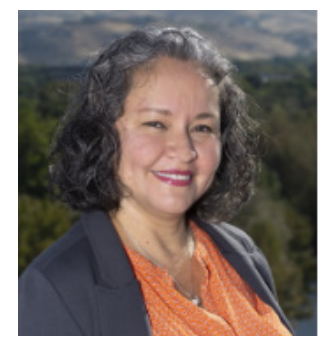
chair of the Educational Technology Department. She teaches research and leadership courses. Before Boise State University, she was a professor at New Mexico State University. She earned a Master's degree in applied mathematics at University of Puerto Rico (2001) and a Ph.D. degree in mathematics education at Virginia Tech (2009). Her research interest includes online education (eMentoring, advising and sense of community), teacher education (including teacher candidates and in-service teachers) as well as the use of tools to support learning in mathematics classrooms. Her work has been presented and published in several national and international venues.

Lida J. URIBE-FLOREZ

Department of Educational Technology, Boise State University

Address: 1910 University Drive, Boise, USA

Phone: +012084264089

E-mail: lidauribeflorez@boisestate.edu 


\section{REFERENCES}

An, H., Shin, S., \& Lim, K. (2009). The effects of different instructor facilitation approaches on students' interactions during asynchronous online discussions. Computers \& Education, 53, 749-760. doi: 10.1016/j.compedu.2009.04.015

Anderson, T., \& Dron, J. (2011). Three generations of distance education pedagogy. The International Review of Research in Open and Distributed Learning, 12(3), 80-97.

Anderson, T., Rourke, L., Garrison, D. R., \& Archer, W. (2001). Assessing teacher presence in a computer conferencing context. Journal of Asynchronous Learning Networks, 5(2), 1-17.

Andresen, M. A (2009). Asynchronous discussion forums: success factors, outcomes, assessments, and limitations. Educational Technology \& Society, 12(1), 249-257.

Barab, S. A., \& Duffy, T. (2012). From practice fields to communities of practice. In D. Jonassen \& S. Land (Eds), Theoretical Foundations of Learning Environments (2nd ed., pp. 29-65), New York, NY: Routledge.

Bennett, S. (2003). Supporting collaborative project teams using computer-based technologies. In T. S. Roberts (Ed.), Online collaborative learning: Theory and practice (pp. 1-27). Hershey, PA: Information Science Publishing.

Berry, S. (2017). Building community in online doctoral classrooms: instructor practices that support community. Online Learning 21(2). doi: 10.24059/olj.v21i2.875

Bond, M. A., \& Lockee, B. B. (2014). Building virtual communities of practice for distance educators. New York, NY: Springer.

Brown, R. E. (2001). The process of community-building in distance learning classes. Journal of Asynchronous Learning Networks, 5(2). Retrieved from https://onlinelearningconsortium.org/jaln_article/theprocess-of-community-building-in-distance-learning-classes-2/

Cho, M-H., \& Tobias, S. (2016). Should instructors require discussion in online courses? Effects of online discussion on community of inquiry, learner time, satisfaction, and achievement. International Review of Research in Open and Distributed Learning, 17(2), 123-140.

Creswell, J. W., \& Creswell, J. D. (2018). Research Design. Qualitative, quantitative, and mixed methods approaches (5th Ed.). Thousand Oaks, CA: SAGE.

Dawson, S. (2006). A study of the relationship between student communication interaction and sense of community. Internet and Higher Education, 9, 153-162.

Desai, M., Hart, J., \& Richards, T. (2009). E-learning: Paradigm shift in education. Education, 129(2), 327-334.

De Wever, B., Schellens, T., Valcke, M., \& Keer, V. (2006). Content analysis schemes to analyze transcripts of online asynchronous discussion groups: A review. Computers \& Education, 46, 6-28.

Fadde, P. J., \& Vu, P. (2014). Blended online learning: Benefits, challenges, and misconceptions. In P. R. Lowenthal, C. S. York, \& J. C. Richardson (Eds.), Online learning: Common misconceptions, benefits, and challenges (pp. 38-48). Hauppauge, YU. Nova Publishers.

Garrison, D. R. (2017). E-learning in the 21st century: A community of inquiry framework for research and practice (3rd ed.). New York, NY: Routledge.

Garrison, D. R. (2011). E-learning in the 21st century: A community of inquiry framework for research and practice (2nd ed.). New York, NY: Routledge.

Garrison, D. R. (2007). Online community of inquiry review: Social, cognitive, and teaching presence issues. Journal of Asynchronous Learning Networks, 11(1), 61-72.

Garrison, D. R., \& Cleveland-Innes, M. (2005). Facilitating cognitive presence in online learning: Interaction is not enough. The American Journal of Distance Education, 19(3), 133-148. 
Garrison, D. R., Anderson, T., \& Archer, W. (2001). Critical thinking, cognitive presence, and computer conferencing in distance education. American Journal of Distance Education, 15(1), 7-23.

Garrison, D. R., Anderson, T., \& Archer, W. (2000). Critical inquiry in a text-based environment: Computer conferencing in higher education. The Internet and Higher Education, 2(2/3), 87-105.

Gunawardena, C. N. (1995). Social presence theory and implications for interaction and collaborative learning in computer conferences. International Journal of Educational Telecommunications, $1(2 / 3), 147-166$.

Hrastinski, S. (2008a). The potential of synchronous communication to enhance participation in online discussions: A case study of two e-learning courses. Information \& Management, 45(7), 499-506. https://doi.org/10.1016/j.im.2008.07.005

Hrastinski, S. (2008b). Asynchronous and synchronous e-learning. Educause Quarterly, 31(4), 51-55.

Haythornthwaite, C., Kazmer, M. M. (Eds.) (2004). Learning, culture, and community in online education. New York: Peter Lang Publishing.

Haythornthwaite, C., Kazmer, M. M., Robins, J., \& Shoemaker, S. (2000). Community development among distance learners: Temporal and technological dimensions. Journal of Computer-Mediated Communication, 6(1). Retrieved from http:/onlinelibrary.wiley.com/ doi/10.1111/j.1083-6101.2000.tb00114.x/full

Hew, K. F., \& Cheung, W. S. (2013). Audio-based versus text-based asynchronous online discussion: Two case studies. Instructional Sciences, 41, 365-380. Doi: 10.1007/s11251-012-9232-7

Hill, J. R. (2012). Learning communities: Theoretical foundations for making connections. In D. Jonassen \& S. Land (Eds), Theoretical Foundations of Learning Environments (2nd ed., pp. 268-285), New York, NY: Routledge.

Ice, P., Curtis, R., Phillips, P., \& Wells, J. (2007). Using asynchronous audio feedback to enhance teaching presence and students' sense of community. Journal of Asynchronous Learning Networks, 11(2), $3-25$.

Jonassen, D. H. (1995). Supporting communities of learners with technology: A vision for integrating technology with learning in schools. Educational Technology, 35(4), 60-63.

Kent, C., Laslo, E., \& Rafaeli, S. (2016). Interactivity in online discussions and learning outcomes. Computers \& Education, 97, 116-128.

Kozan, K., \& Richardson, J. C. (2014). Interrelationships between and among social, teaching, and cognitive presence. Internet and Higher Education, 21, 68-73. doi:10.1016/j.iheduc.2013.10.007

Kreijns, K., Kirschner, P. A., \& Jochems, W. (2003). Identifying the pitfalls for social interaction in computersupported collaborative learning environments: a review of the research. Computers in Human Behavior 19, 335-353.

Lenning, O., \& Ebbers, L. (1999). The powerful potential of learning communities: Improving education for the future. Washington, DC: George Washington University, Graduate School of Education and Human Development.

Liu, X., Magjuka, R. J., Bonk, C. J., \& Lee, S. (2007). Does sense of community matter? An examination of participants' perceptions of building learning communities in online courses. The Quarterly Review of Distance Education, 8(1), 9-24.

Ludwig-Hardman, S., \& Dunlap, J. C. (2003). Learner support services for online students: Scaffolding for success. The International Review of Research in Open and Distance Learning, 4(1). Retrieved from http://www.irrodl.org/content/v4.1/dunlap.html

Luo, N., Zhang, M., \& Qi, D. (2017). Effects of different interactions on students' sense of community in e-learning environment. Computers \& Education, 115, 153-160.

Luppicini, R. (Ed.). (2007). Online learning communities. Charlotte, NC: Information Age Publishing. 
Martin, F., Parker, M. A., \& Deale, D. F. (2012). Examining interactivity in synchronous virtual classrooms. The International Review of Research in Open and Distributed Learning, 13(3), 228-261. Retrieved from http://www.irrodl.org/index.php/irrodl/article/view/1174/2253

Misanchuk, M., \& Anderson, T. (2001). Building community in an online learning environment: Communication, cooperation and collaboration. Proceedings of the Teaching Learning and Technology Conference, Middle Tennessee State University. Retrieved from https://files.eric.ed.gov/ fulltext/ED463725.pdf

McInnerney, J. M., \& Roberts, T. S. (2004). Online learning: Social interaction and the creation of a sense of community. Educational Technology \& Society, 7(3), 73-81.

Oha, H. J., Ozkaya, E., \& LaRose, R. (2014). How does online social networking enhance life satisfaction? The relationships among online supportive interaction, affect, perceived social support, sense of community, and life satisfaction. Computers in Human Behavior, 30, 69-78.

Palloff, R. M., \& Pratt, K. (2007). Building online learning communities: Effective strategies for the virtual classroom. San Francisco, CA: Jossey-Bass.

Palloff, R. M., \& Pratt, K. (2004). Collaborating Online: Learning Together in Community. San Francisco, CA: Jossey-Bass.

Palloff, R. M., \& Pratt, K. (1999). Building learning communities in cyberspace. San Francisco, CA: JosseyBass.

Reeves, T.C., Herrington, J., \& Oliver, R. (2004). A development research agenda for online collaborative learning. Educational Technology Research \& Development, 52(4), 53-65.

Retallick, J., Cocklin, B. and Coombe, K. (1999). Learning communities in education: Issues, strategies and contexts. New York, NY: Routledge.

Roberts, E., \& Lund, J. (2007). Exploring e-learning community in a global postgraduate programme. In R. Andrews \& C. Haythornthwaite (Eds.), The SAGE handbook of e-learning research (pp. 487-503). Thousand Oaks, CA: SAGE.

Rovai, A. P. (2007). Facilitating online discussions effectively. The Internet and Higher Education, 10(1), 77-88.

Rovai, A. P. (2002a). Development of an instrument to measure classroom community. The Internet and Higher Education, 5(3), 197-211.

Rovai, A. P. (2002b). Building sense of community at a distance. International Review of Research in Open and Distance Learning, 3(1),

Rovai, A. P. (2002c). Sense of community, perceived cognitive learning, and persistence in asynchronous learning networks. The Internet and Higher Education, 5(4), 319-332. doi:10.1016/S10967516(02)00130-6

Rovai, A. P. (2001). Building classroom community at a distance: A case study. Educational Technology Research and Development, 49(4), 33-48.

Saldana, J. (2015). The coding manual for qualitative researchers (3rd Ed.). Thousand Oaks, CA: SAGE.

Scardamalia, M., \& Bereiter, C. (1994). Computer support for knowledge-building communities. The Journal of the Learning Sciences, 3(3), 265-283).

Shackelford, J., \& Maxwell, M. (2012a). Sense of community in graduate online education: Contribution of learner to learner interaction. International Review of Research in Open and Distance Learning, 13(4), 228-249. Retrieved from http://www.irrodl.org/index.php/irrodl/article/view/1339/2317

Shackelford, J., \& Maxwell, M. (2012b). Contribution of learner-instructor interaction to sense of community in graduate online education. Journal of Online Learning and Teaching, 8(4), 248-260.

Shea, P. (2006). A study of students' sense of learning community in online environments. Journal of Asynchronous Learning Networks, 10(1), 35-44 Retrieved from http://onlinelearningconsortium. org/sites/default/files/v10n1_4shea.pdf 
Shea, P., Li, C., \& Pickett, A. (2006). A study of teaching presence and student sense of learning community in fully online and web-enhanced college courses. Internet and Higher Education, 9, 175-190.

Swan, K. (2003). Learning effectiveness: What the research tells us. In J. Bourne \& J. C. Moore (Eds.), Elements of quality online education: Practice and direction (pp. 13-45). Needham, MA: Sloan Center for Online Education.

Swan, K. (2002). Building learning communities in online courses: The importance of interaction. Education, Communication \& Information, 2(1), 23-49.

Swan, K., Shea, P., Fredericksen, E., Pickett, A., Pelz, W., \& Maher, G. (2000) Building knowledge building communities: consistency, contact and communication in the virtual classroom. Journal of Educational Computing Research, 23, 389-413.

Stoll, L., Bolam, R., McMahon, A., Wallace, M., \& Thomas, S. (2006). Professional learning communities: A review of the literature. Journal of Educational Change, 7(4), 221-258.

Trespalacios, J., \& Rand, J. (2015). Using asynchronous activities to promote sense of community and learning in an online course. International Journal of Online Pedagogy and Course Design, 5(4), $1-13$.

Tu, C. H. (2004). Online collaborative learning communities: Twenty-one designs to building an online collaborative learning community. Westport, CT Libraries Unlimited.

Wegerif, R. (1998). The social dimension of asynchronous learning networks. Journal of Asynchronous Learning Networks, 2(1), 34-49. 


\section{APPENDIX A}

\section{Asynchronous Discussion Questions}

\section{Discussion \#1}

- Question \#1: In chapter 2, Creswell discussed the process of identifying a research problem. Describe a topic in the Educational Technology field that you are interested and a research problem that you would like to investigate. Please, also identify the audience who would read and potentially benefit from your potential research study.

- Question \#2: Using the educational topic and the research problem you identified in Question 1, please discuss whether your research problem can and should be investigated (pages 61-63). In your post, please include answers to the questions asked by Creswell (Can you gain access to people and sites? Can you find the time, locate resources, and use your skills? should the problem be researched?)

\section{Discussion \#2}

- Question \#1: With the new insights gathered from Creswell's Chapter 4, turn the research topic you have chosen into a quantitative study. Please, include a brief description of the research topic/problem and write a quantitative purpose statement and two or three quantitative research questions.

- Question \#2: Using the quantitative study that you described in question \#1, design a quantitative data collection procedure. Specify the population and sample, the permissions that you will need, the types of quantitative information you will collect, whether you will develop or locate an instrument, and the administrative procedures that will ensure standardization and ethical practices.

\section{Discussion \#3}

- Question \#1: Using the same research topic you have been working so far, assume you are going to design a qualitative study. Please, (1) write a qualitative purpose statement, and a central question and sub-questions (follow Creswell's scripts to generate these items), (2) determine people and research site you would like to study, and the type of purposeful sampling you would use, (3) The type of data you would record and what protocols you would use, and finally (4) list the anticipated field and ethical issues that you would need to consider before you conduct your data collection.

- Question \#2: Since you have now reviewed all the different steps in the process of educational research, in your own words, describe this process in metaphorical terms (ex., "the process of educational research is like learning to read another language."). Please, explain your metaphor. 


\section{APPENDIX B}

\section{End-of-Course Students' Evaluations}

\begin{tabular}{|l|c|c|}
\hline \multicolumn{1}{|c|}{ Question } & Responses & Mean (From 5)* \\
\hline The instructor seemed prepared for class & 9 & 4.89 \\
\hline The instructor fostered learning in this course & 9 & 4.89 \\
\hline The assessment methods were clearly explained & 9 & 4.89 \\
\hline Assessments and/or other products reflect course objectives & 9 & 5.0 \\
\hline The readings were aligned with course objectives & 9 & 5.0 \\
\hline Peer collaboration was offered & 9 & 4.78 \\
\hline The instructor has a thorough knowledge of the subject & 9 & 4.89 \\
\hline The instructor stimulates interest in the subject & 8 & 4.88 \\
\hline The instructor communicates ideas and information clearly & 9 & 4.89 \\
\hline The instructor is genuinely interested in helping students & 9 & 5.0 \\
\hline The instructor treats students with respect & 9 & 5.0 \\
\hline I would take another class from this instructor & 9 & 4.89 \\
\hline
\end{tabular}

*1: Strongly Disagree; 2: Disagree; 3: Neutral; 4: Agree; 5: Strongly Agree

\section{APPENDIX C}

\section{Interview Questions}

1. In this graduate course, you have experienced several collaborative activities (VoiceThread introductions, small-groups VoiceThread presentations, whole-class discussions, and peer feedback). What was the most relevant one from you and why?

2. What was the less relevant collaborative activity in this course and why?

3. What would you recommend to improve the less relevant activity?

4. Do the collaborative activities made you feel connected to others in this course?

5. Do the collaborative activities made you feel that you had opportunities to learn about educational research? 